\title{
FAKTOR - FAKTOR YANG BERPENGARUH TERHADAP PELAKSANAAN INISIASI MENYUSUI DINI PADA IBU BERSALIN
}

\section{FACTORS THAT INFLUENCE THE IMPLEMENTATION OF INITIATED BREASTFEEDING IN LABOR}

\author{
Apri Sulistianingsih \\ Fakultas Kesehatan, Universitas Muhammadiyah Pringsewu \\ Email: sulistianingsih.apri@gmail.com
}

\begin{abstract}
Factors That Influence The Implementation Of Initiated Breastfeeding In Labor, Early breastfeeding initiation (EBI) has many benefits for the mother and baby that can prevent morbidity and mortality. This study was to find out the factors that influence the implementation of early breastfeeding initiation in mothers giving birth at PMB Pringsewu Lampung. The design of this study was a multivariate study, which used an observational analytic research design with a crossectional approach. The sample in this study amounted to 28 people who met the inclusion and exclusion criteria. This research was conducted in June 2019. The sampling technique in this study used a cluster sampling technique to place PMB representing Pringsewu. Multivariate analysis found that family support was the most influential factor in the implementation of EBI in maternity ( $p$ value $=0.005)$. It is recommended that institutions providing delivery services be able to provide education to families before delivery so that they can facilitate the implementation of EBI

Keywords: Early Breastfeeding Initiation, Colostrum, Family Support
\end{abstract}

\begin{abstract}
Abstrak: Faktor - Faktor Yang Berpengaruh Terhadap Pelaksanaan Inisiasi Menyusui Dini Pada Ibu Bersalin . Insiasi Menyusui Dini (IMD) memiliki banyak manfaat pada ibu dan bayi yang dapat mencegah morbiditas dan mortalitas. Penelitian ini untuk mengetahui faktor - faktor yang berpengaruh terhadap pelaksanaan inisiasi menyusui dini pada ibu bersalin di PMB Pringsewu Lampung. Rancangan penelitian ini adalah penelitian multivariat, yang menggunakan desain penelitian analitik observasional dengan pendekatan crossectional. Sampel pada penelitian ini berjumlah 28 orang yang memenuhi kriteria inklusi dan eksklusi. Penelitian ini dilaksanakan pada bulan Juni 2019. Teknik pengambilan sampel dalam penelitian ini menggunakan teknik cluster sampling untuk tempat PMB yang mewakili Pringsewu. Hasil penelitian didapatkan Sebagian besar ibu berhasil melakukan IMD pada 1 jam pertema $(53,6 \%)$. Analisis multivariat didapatkan Dukungan keluarga merupakan faktor yang paling berpengaruh terhadap pelaksanaan IMD pada ibu bersalin ( $\mathrm{p}$ value = 0,005). Disarankan institusi penyedia pelayanan persalinan untuk dapat memberikan edukasi kepada keluarga sebelum persalinan agar dapat memfasilitasi pelaksanaan IMD
\end{abstract}

Kata Kunci: Inisiasi Menyusui Dini, Kolostrum, Dukungan KeluargaAbstrak

\section{PENDAHULUAN}

Periode persalinan meliputi masa transisi kritis bagi ibu, bayi, dan keluarganya secara fisiologis, emosional dan sosial. Kelahiran bayi merupakan peristiwa penting bagi kehidupan seorang pasien dan keluarganya, sangat penting untuk diingat bahwa persalinan adalah proses yang normal dan merupakan kejadian yang sehat. Dukungan yang terus menerus dan penatalaksanaan yang terampil dari bidan dapat menyumbangkan suatu pengalaman melahirkan menyenangkan dengan hasil persalinan yang sehat dan memuaskan terutama untuk ibu dan bayi. (Sulistyawati \& Nugraheny,2012).

Hasil Survei Demografi dan Kesehatan Indonesia (SDKI) tahun 2012, secara nasional AKN pada tahun 2012 sebesar 19 per 1000 kelahiran hidup (KH). Angka ini menurun dibandingkan tahun 2007 yaitu 20 per $1000 \mathrm{KH}$ dan di tahun 2002 yaitu 23 per $1000 \mathrm{KH}$. AKB juga mengalami penurunan dibandingkan hasil SDKI tahun 2007 dan 2002 dimana AKB tahun 2012 adalah 32 per $1000 \mathrm{KH}$ sedangkan pada tahun 2007 sebesar 35 per 1000 kelahiran hidup. Pola SDKI 2012 sama dengan pola SDKI 2007 yaitu lebih dari $3 / 4$ dari semua kematian balita terjadi dalam tahun pertama kehidupan anak dan mayoritas kematian bayi terjadi pada periode neonatus. Perhatian kepada upaya penurunan Angka Kematian Neonatal (1-28 hari) menjadi penting karena kematian neonatal memberi konstibusi terhadap 56\% kematian bayi (SDKI, 2012).

Berdasarkan Rencana Strategis Kabupaten Pringsewu 2017-2022. Angka kematian bayi di Kabupaten Pringsewu masihlah tinggi tahun 2016 yaitu 69/1000 kelahiran hidup. Rencana yang ditargetkan Kabupaten Pringsewu tahun 2022 yaitu 29/1000 kelahiran hidup. Oleh sebab itu perlu diupayakan untuk menurunkan kematian bayi di Kabupaten Pringsewu.

Faktor penyebab kematian neonatal diakibatkan infeksi 36\%, prematuritas $28 \%$, dan asfiksia $23 \%$. Salah satu cara yang dapat dilakukan untuk meningkatkan kekebalan tubuh neonatal yaitu memberikan kolostrum sesegera mungkin kepada bayi baru lahir yang 
mengandung immunoglobulin A (IgA) yang membantu melapisi usus bayi yang masih rentandan mencegah kuman memasuki usus bayi melalui Inisiasi Menyusui Dini (IMD) (SDKI, 2012). Sejak tahun 2006 IMD merupakan program yang sedang gencar-gencarnya dianjurkan pemerintah. Program ini memang popular diIndonesia beberapa tahun belakangan ini. IMD harus dilakukan langsung saat bayi baru lahir tanpa boleh ditunda dengan kegiatan menimbang atau mengukur bayi. Dalam mencapai keberhasilan dalam IMD tersebut dibutuhkan waktu dan prosesnya berlangsung Skin to skin antara bayi dan ibu (Maryunani, 2012).

Program inisiasi menyusu dini (IMD) sangat perlu dilakukan kepada bayi yang baru lahir untuk mencegah tingginya kematian neonatal. Pada IMD, bayilah yang diharapkan berusaha untuk menyusu. Pada jam pertama, bayi berhasil menemukan payudara ibunya. Inilah awal hubungan menyusui antara bayi dan ibunya, yang akhirnya berkelanjutan dalam kehidupan ibu dan bayi. (Fikawati \& Syafiq, 2009).

Cakupan inisiasi menyusu dini (IMD) di Indonesia masih rendah. Hasil Riskesdas tahun 2013 hanya 34,5\% bayi yang menyusu kurang dari satu jam setelah persalinan, sebanyak $35,2 \%$ pada 1 6 jam kedua, sebanyak $3,7 \%$ pada 7-23 jam, sebanyak 13,0 pada pada 24-47 jam dan 13,7\% setelah 48 jam. Padahal keberhasilan pelaksanaan IMD berhubungan dengan keberhasilan pemberian ASI Eksklusif pada bayi.(Fikawati \& Syafiq, 2009). Berdasarkan Riskesdas (2013) di Provinsi Lampung Cakupan IMD juga masih cukup rendah. Ibu yang mulai menyusui pada $<1$ jam pertama hanya $24,1 \%$, pada $1-6$ jam pertama sebanyak $46,3 \%$, pada $7-23$ jam pertam $4,1 \%$, pada $24-47$ jam sebanyak $13,6 \%$ dan > 48 jam sebanyak $12,0 \%$.

Menurut Roesli (2012) dan Maryunani (2012) terdapat beberapa faktor yang mempengaruhi pelaksanaan IMD. Faktor tersebut diantaranya adalah pengetahuan dan sikap ibu, pengeluaran kolostrum, peran tenaga kesehatan, paritas, dukungan keluarga, keadaan ibu dan keadaan bayi. Sedangkan Menurut penelitian Issyaputri dkk (2010) menjelaskan faktor yang berhubungan dengan pelaksanaan IMD adalah pengetahuan dan sikap ibu, dukungan keluarga dan dukungan dari tenaga kesehatan.

Prasetyono (2012) menyatakan bahwa dalam proses IMD dibutuhkan pengetahuan dan kesiapan mental ibu. Ibu tidak perlu merasa terganggu dengan adanya bayi yang diletakkan di atas perutnya. Saat inilah pendampingan suami dan keluarga sangat dibutuhkan oleh seorang ibu setelah melahirkan untuk melakukan IMD. Beberapa tindakan perhatian yang dapat dilakukan suami seperti mengungkapkan kata-kata sebagai penenang hati ibu dan ucapan penuh kasih sayang.

Berdasarkan penelitian Fitriana (2017) menjelaskan ada hubungan yang signifikan antara pendampingan suami pada ibu bersalin dengan keberhasilan Inisiasi Menyusu Dini di Kecamatan Depok Kabupaten Sleman.
Pendampingan suami pada ibu bersalin akan meningkatkan keberhasilan ibu bersalin untuk menyusui bayinya sedini mungkin. dukungan suamimerupakan salah satu sumber dukungan dari keluarga yang sangat ampuh manfaatnya, karena dapat memberikan dampak yang positif bagi ibu melahirkan dan menyusui. Salah satu peran suami yang paling bermanfaat adalah menciptakan suasana yang menyenangkan. Menyenangkan disini adalah keadaan dimana seorang istri merasa nyaman, aman karena merasa terlindungi dan bahagia karena ibu merasa mendapatkan dukungan serta kasih sayang dari suami.

Selain pendampingan dari keluarga khususnya suami, maka dukungan dari petugas kesehatan berpengaruh terhadap pelaksanaan IMD. Hal ini dikarenakan tenaga kesehatan berperan menangani langsung proses persalinan ibu dan ibu tidak dapat melakukan IMD tanpa dukungan dan fasilitas dari tenaga kesehatan.

Pendidikan dan konseling yang memadai yang diberikan oleh petugas kesehatan diperlukan untuk memperbaiki praktik eksklusif menyusui dengan meningkatkan inisiasi menyusui tepat waktu dalam waktu 1 jam setelah persalinan, seperti bisa dilakukan dengan memberikan konseling mencakup diskusi tentang manfaat pemberian ASI secara eksklusif, menjelaskan dan memperagakan prosedur yang benar untuk menyusui, dan diskusi tentang diet yang cocok untuk menyusui ibu. (Paramashanti, 2016).

Hasil Laporan Dinas Kesehatan Kabupaten Pringsewu Cakupan ASI eksklusif sudah tinggi pada tahun 2016 yaitu 78,95\%. Hal ini menjelaskan seharunya cakupan IMD di Kabupaten Pringsewu juga tinggi. Namun sampai saat ini belum didapatkan informasi resmi terkait cakupan pelaksanaan IMD dan faktor yang mempengaruhinya di Kabupaten Pringsewu. Praktik Mandiri Bidan (PMB) merupakan lini pertama bagi ibu untuk bersalin di komunitas dengan persalinan yang normal. Praktik IMD lebih memungkinkan untuk dilaksanakan pada persalinan yang normal, sehingga PMB merupakan tempat yang sesuai untuk penelitian ini. Tujuan penelitian ini untuk mengetahui faktor - faktor yang berpengaruh terhadap pelaksanaan inisiasi menyusui dini pada ibu bersalin di PMB Pringsewu Lampung.

\section{METODE}

Rancangan penelitian ini adalah penelitian multivariat, yang menggunakan desain penelitian analitik observasional dengan pendekatan crossectional. Populasi dalam penelitian ini adalah semua ibu bersalin yang bersalin di PMB Pringsewu Lampung pada saat penelitian berjalan. Sampel pada penelitian ini berjumlah 28 orang yang memenuhi kriteria inklusi dan eksklusi. Penelitian ini dilaksanakan pada bulan Juni 2019. Teknik pengambilan sampel dalam penelitian ini menggunakan teknik cluster 
sampling untuk tempat PMB yang mewakili Pringsewu. Alat ukur dalam penelitian ini peneliti menggunakan instrumen berupa: Lembar A untuk identitas responden, untuk mengetahui karakteristik responden. Lembar B lembar observasi untuk mengetahui pelaksanaan IMD, dan pengeluaran Kolostrum Data dianalisis dengan menggunakan distribusi frekuensi, uji statistic chi square, dan uji regresi logistic ganda.

\section{HASIL}

Karakteristik subjek penelitian Pada tabel berikut akan dijelaskan karakteristik subjek penelitian tentang usia, paritas, pendidikan dan pendapatan. Pada tabel 1 menggambarkan karakteristik repsonden. Pada usia responden sebagian sebagian besar berusia 20-35 tahun yang merupakan usia tidak berisiko $85,7 \%$. Pada paritas menunjukkan sebagian besar ibu multigravida $53,6 \%$. Pada pendidikan sebagian besar berpendidikan SMA $64,3 \%$.

Pada Pendapatan menunjukkan sebagian besar pendapatan $\geq$ UMR $64,3 \%$.

Tabel 1 Karakteristik Subjek Penelitian

\begin{tabular}{|c|c|c|}
\hline Variabel & $\mathrm{n}$ & $\%$ \\
\hline \multicolumn{3}{|l|}{ Usia } \\
\hline Tidak Berisiko & 24 & 85,7 \\
\hline Berisiko & 4 & 14,3 \\
\hline \multicolumn{3}{|l|}{ Paritas } \\
\hline Primigravida & 13 & 46,4 \\
\hline Multigravida & 15 & 53,6 \\
\hline \multicolumn{3}{|l|}{ Pendidikan } \\
\hline SD & 1 & 3,6 \\
\hline SMP & 5 & 17,9 \\
\hline SMA & 18 & 64,3 \\
\hline PT & 4 & 14,3 \\
\hline \multicolumn{3}{|l|}{ Pendapatan } \\
\hline$\geq \mathrm{UMR}$ & 18 & 64,3 \\
\hline$<\mathrm{UMR}$ & 10 & 35,7 \\
\hline
\end{tabular}

Distribusi frekuensi pengeluaran kolostrum, peran tenaga kesehatan, dukungan keluarga dan keberhasilan IMD Di PMB Pringsewu
Pada tabel 2 dijelaskan tentang distribusi frekuensi masing -masing variabel. Sebagian besar ibu berhasil melakukan IMD pada 1 jam pertama $(53,6 \%)$. Pengeluaran kolostrum separuh responden mengeluarkan kolostrum (50\%). Pada peran petugas kesehatan didapatkan sebagian besar tenaga kesehatan memfasilitasi pelaksanaan IMD (89,3\%). Pada Dukungan keluarga, sebagian besar keluarga kurang mendukung pelaksanaan IMD $(53,6 \%)$ Faktor - factor yang berhubungan dengan pelaksanaan inisiasi menyusui dini pada ibu bersalin di PMB Pringsewu Lampung Tabel 2 Distribusi frekuensi pengeluaran kolostrum, peran tenaga kesehatan, dukungan keluarga dan keberhasilan IMD Di PMB Pringsewu

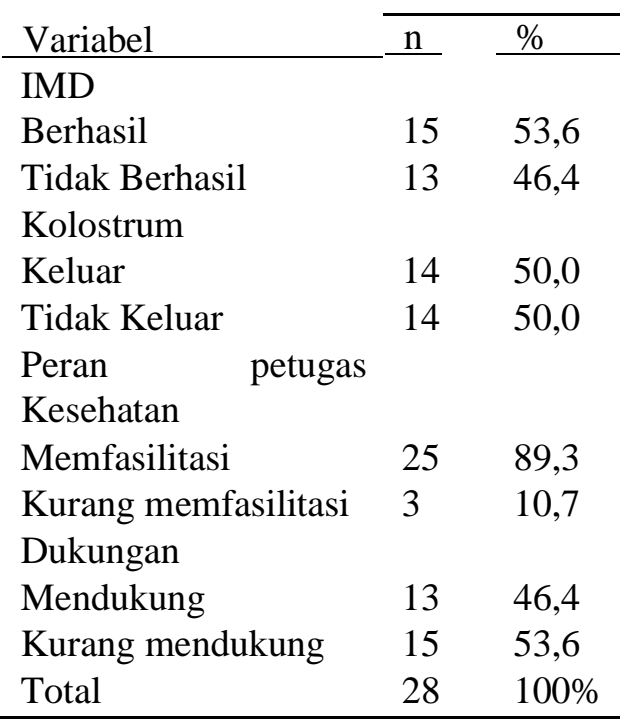

Pada tabel berikut akan menjelaskan hubungan pengeluran kolostrum, peran petugas kesehatan dan dukungan keluarga dengan keberhasilan IMD, analisis menggunakan uji chi square dengan alpha 0,05 . 
Tabel 3 Faktor - faktor yang berhubungan dengan pelaksanaan inisiasi menyusui dini pada ibu bersalin di PMB Pringsewu Lampung

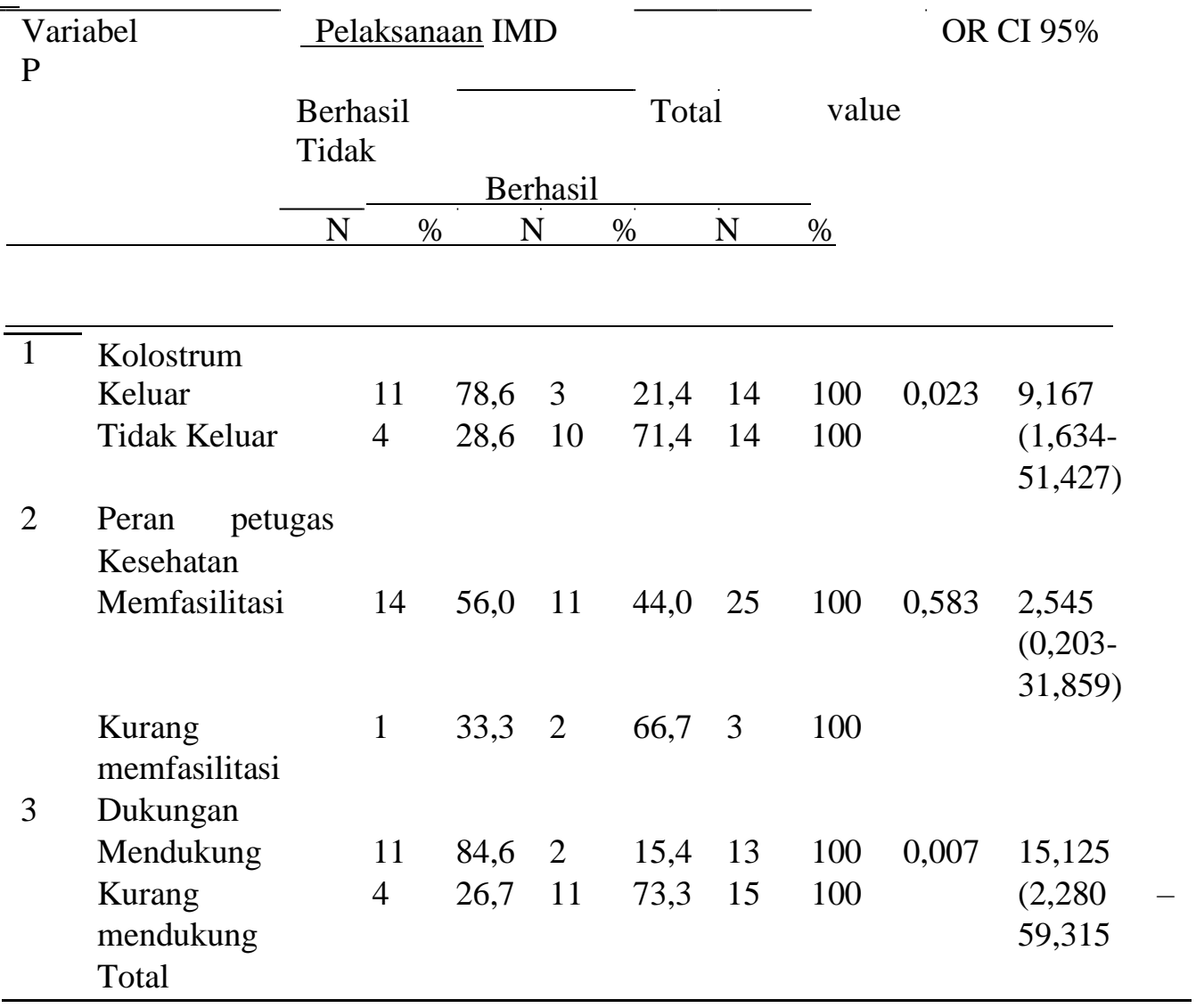


Hasil analisis pada tabel 3 didapatkan factor yang berhubungan dengan keberhasilan IMD di PMB Pringsewu. Pada responden yang tidak keluar kolostrum sebanyak 71,4\% tidak berhasil IMD. Hasil analisis didapatkan $\mathrm{p}$ value 0,023 yang artinya ada hubungan pengeluaran kolostrum dengan pelaksanaan inisiasi menyusui dini pada ibu bersalin Di PMB Pringsewu Lampung. Pada petugas kesehatan yang kurang memfasilitasi IMD sebanyak 66,7\% ibu tidak berhasil IMB, meskipun demikian didapatkan nilai $\mathrm{p}$ value $=0,583$ yang berarti tidak ada hubungan peran petugas kesehatan dengan dengan pelaksanaan inisiasi menyusui dini pada ibu bersalin Di PMB Pringsewu Lampung. Pada dukunngan keluarga yang kurang mendukung pelaksanaan IMD sebanyak $73,3 \%$ ibu tidak berhasil IMB, hasil statistic didapatkan nilai $\mathrm{p}$ value $=0,007$ yang berarti ada hubungan dukungan keluarga dengan dengan pelaksanaan inisiasi menyusui dini pada ibu bersalin Di PMB Pringsewu Lampung. Faktor yang paling berpengaruh terhadap Pelaksanaan Inisiasi Menyusui Dini Pada Ibu Bersalin Di PMB Pringsewu Lampung Analisis mulivariat untuk melihat faktor independen mana yang paling berpengaruh terhadap Pelaksanaan Inisiasi Menyusui Dini Pada Ibu Bersalin. Pada tabel 3 didapakan $\mathrm{p}$ value yang $<0,25$ adalah variabel pengeluaran kolostrum dan dukungan keluarga, oleh sebab itu variabel yang diikutkan dalam analisis multivariate adalah pengeluran kolostrum dan dukungan keluarga dengan analisis regresi logistic gadana

Tabel 4 Analisis Multivariat Faktor yang paling berpengaruh terhadap Pelaksanaan Inisiasi Menyusui

Dini Pada Ibu Bersalin Di PMB Pringsew $\underline{u}$ Lampung

\begin{tabular}{|c|c|c|c|}
\hline \multicolumn{2}{|c|}{ Variabel } & Koef $\beta$ & $\operatorname{SE}(\beta)$ \\
\hline \multicolumn{4}{|c|}{ I. Model 1} \\
\hline \multicolumn{2}{|l|}{ Kolostrum } & 1,504 & 0,998 \\
\hline \multicolumn{2}{|l|}{ Dukungan } & 2,197 & 1,027 \\
\hline \multicolumn{2}{|l|}{ Konstanta } & $-2,197$ & 0,905 \\
\hline \multicolumn{4}{|l|}{ II.Model 2} \\
\hline \multicolumn{2}{|l|}{ Dukungan } & 2,716 & 0,965 \\
\hline \multicolumn{2}{|l|}{ Konstanta } & $-1,705$ & \\
\hline 0,769 & 0,027 & & \\
\hline Ket: & Akurasi model & $82,3 \%$. & \\
\hline $\begin{array}{l}\text { POR* adj } \\
\text { (adjusted) }\end{array}$ & $=$ Prevalence & Odds $\mathrm{R}$ & \\
\hline
\end{tabular}

Pada Dukungan keluarga, sebagian besar Berdasarkan tabel 4 menunjukkan pemodelan factor yang paling berpengaruh terhadap pelaksanaan IMD pada ibu bersalin. Pada pemodelan pertama didapatkan factor yang berpengaruh adalah factor dukungan keluarga (pvalue $=0,032$ ) sedangkan variabel kolostrum tidak berpengaruh ( $\mathrm{p}$ value $=0,132)$. Selanjutnya variabel kolostrum dikeluarkan dari model dan didapatkan perubahan OR $<10 \%$ yang menjukkan variabel pengeluaran kolostrum bukan merupakan variabel confounding dan dapat dikeluarkan dari pemodelan. Hasil analisis model kedua didapatkan bahwa dukungan keluarga merupakan faktor yang paling berpengaruh terhadap pelaksanaan IMD pada ibu bersalin ( $\mathrm{p}$ value $=0,005)$. Berdasarkan hasil uji statistik didapatkan nilai POR $15,125(95 \%$ CI $2,280-$

50,315) hal ini berarti bahwa ibu yang kurang didukung keluarga dalam memfasilitasi IMD akan berisiko 18,0 kali pada tidak berhasil melaksanakan IMD dibandingkan dengan ibu yang didukung keluarga memfasilitasi IMD.

\section{PEMBAHASAN}

Persalinan adalah proses pengeluaran hasil konsepsi yang telah cukup bulan di luar kandungan melalui jalan lahir atau melalui jalan lain, dengan bantuan atau tanpa bantuan (Sulistyawati \& Nugraheny, 2012).

Pada penelitian ini sebagian besar ibu berhasil melakukan IMD pada 1 jam pertema (53,6\%).IMD menurut Roesli (2012) adalah bayi mulai menyusu sendiri segera setelah lahir.

Menurut Depkes (2009) IMD adalah meletakkan bayi menempel di dada atau perut Ibu segera setelah lahir, membiarkannya mencari putting kemudian menyusu sampai puas. Apabila bayi tidak menghisap puting susu pada setengah jam setelah persalinan, hormone prolaktin akan turun dan sulit merangsang prolaktin sehingga ASI baruakan keluar pada hari ke-3 atau lebih, sehingga akan memaksa petugas kesehatan memberi makanan PASI karena bayi yang tidak mendapat cukup ASI akan red (Bgesti, 2012) Nilatprumnya pada proses persalinan sudah terjadi pengeluaran kolostrum. Pada penelitian ini

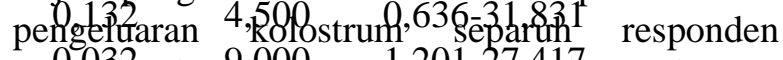
metrgę? medd1 Rung perdkstanaan IMD $(53,6 \%)$.

Hasil analisis pada tabel 4.3 didapatkan

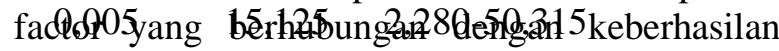
IMD di PMB Pringsewu. Pada responden yang tidak keluar kolostrum sebanyak 71,4\% tidak berhasil IMD. Hasil analisis didapatkan $\mathrm{p}$ value 0,023 yang artinya ada hubungan pengeluaran kolostrum dengan pelaksanaan inisiasi menyusui dini pada ibu bersalin Di PMB Pringsewu Lampung.

Menurut penelitian Ramadhanti (2016), rata- rata waktu yang di butuhkan bayi dalam keberhasilan Inisiasi Menyusui Dini adalah 55 menit. Meskipun demikian ada juga bayi yang tidak berhasil melaksanakan Inisiasi 
Menyusui Dini yang dikarenakan oleh faktor kolostrum dan puting susu yang tidak keluar.

Kolostrum adalah Air Susu Ibu (ASI) pertama keluar yang berwarna kekuningan. Kolostrum mengandung antibody bagi bayi yang bermanfaat untuk meningkatkan daya tahan tubuh (Mayunani, 2012).

Menurut penelitian Bimerew (2016) menjelaskan bahwa kolostrum sangat penting bagi ibu dan bayi untuk meningkatkan bounding attachment. Kolostrum juga berhubungan dengan waktu keberhasilan inisiasi menyusui dini Persepsi yang salah tentang kolostrum tidak keluar atau jumlahnya tidak memadai sehingga diperlukan cairan lain. Hal ini tidak tepat karena kolostrum cukup dijadikan makanan pertama bayi baru lahir. Volume kolostrum berkisar 150-300 ml/24 jam. Selain itu kolostrum tidak baik/ berbahaya untuk bayi. Hal ini tidak tepat karena kolostrum sangat diperlukan untuk tumbuh kembang bayi. Selain sebagai imunisasi pertama dan mengurangi penyakit kuning pada bayi baru lahir, kolostrum melindungi dan mematangkan dinding usus yang masih muda. Menurut penelitian yang dilakukan oleh Solikah (2015) menjelaskan hampir setengah responden kolostrumnya keluar sebanyak 13 orang $(43,3 \%)$ pada kehamilan trimester III. Mengingat sangat pentingnya kolostrum dalam hal ini dibutuhkan peran bidan sebagai educator untuk memberikan pengetahuan dan pelaksanaan kepada ibu hamil diantaranya pemberiaan KIE pada ibu hamil untuk membantu pengeluaran kolostrum sebelum persalinan

Pada petugas kesehatan yang kurang memfasilitasi IMD sebanyak $66,7 \%$ ibu tidak berhasil IMB, meskipun demikian didapatkan nilai $p$ value $=0,583$ yang berarti tidak ada hubungan peran petugas kesehatan dengan dengan pelaksanaan inisiasi menyusui dini pada ibu bersalin Di PMB Pringsewu Lampung. Petugas kesehatan yang berperan besar dalam proses persalinanya. Setiap ibu yang hendak melahirkan harus diinformasikan dan membimbing ibu-ibu mengenai hal kebutuhan atau hal yang kemungkinan akan terjadi dalam proses persalinan. Peran tenaga kesehatan yaitu memberikan informasi dan bimbingan tersebut harus bekerja sama dengan ibu yang hendak melahirkan tentang pentingnya informasi mengenai menyusukan bayi sesaat setelah lahir Penelitian ini tidak sejalan dengan penelitian Ariani dkk (2015) menjelaskan bahwa bidan berperan penting dalam mengimplementasikan IMD pada satu jam pertama. Bidan merupakan pemimpin dalam persalinan yang memberikan peranan sangat besar, bidan dapat memfasilitasi ibu untuk melaksanakan IMD seawal mungkin bila kondisi ibu memungkinkan.
Perbedaan dengan penelitian ini dapat disebabkan oleh petugas kesehatan lebih dari sebagian besar telah memfasilitasi pelaksanaan IMD (89,3\%), hanya terdapat tiga responden yang merasa kurang difasilitasi IMD (10,5\%). Hal ini juga didukung oleh penelitian Khanal (2015) yang menyatakan, tenaga kesehatan yang pemperoleh pelatihan keterampilan dalam mendukung praktik menyusui akan lebih merekomendasikan kepada ibu bersalin untuk melaksanakan IMD Pada dukunngan keluarga yang kurang mendukung pelaksanaan IMD sebanyak 73,3\% ibu tidak berhasil IMB, hasil statistic didapatkan nilai $\mathrm{p}$ value $=0,007$ yang berarti ada hubungan dukungan keluarga dengan dengan pelaksanaan inisiasi menyusui dini pada ibu bersalin Di PMB Pringsewu Lampung Menurut (Roesli, 2012) bayi dapat menemukan sendiri payudara ibu. Libatkan ayah atau keluarga terdekat untuk menjaga bayi sambil member dukungan pada ibu. Dukungan yang kurang tepat dapat menyebabkan pelaksanaan IMD dapat terhambat.

Hasil penelitian Saleh (2011) menunjukkan bahwa dukungan suami yang rendah dalam praktik ASI Eksklusif sehingga mendorong ibu dalam memberikanmakanan dan susu formula kepada bayinya. Selain itu keluarga yang kurang memfasilitasi IMD dapat mencegah keberhasilan pelaksanaan IMD.

Berdasarkan analisis tersebut maka peneliti menyimpulkan bahwa pengeluaran kolostrum dan dukungan keluarga merupakan factor yang berhubungan dengan pelaksanaan IMD pada ibu bersalin. Analisis dilanjutkan pada multivariate menggunakan regresi logistic ganda Pada penelitian ini didapatkan bahwa dukungan keluarga merupakan factor yang paling berpengaruh terhadap pelaksanaan IMD pada ibu bersalin ( $p$ value $=0,005)$.

Berdasarkan hasil uji statistic didapatkan nilai POR 15,125(95\% CI 2,280-50,315) hal ini berarti bahwa ibu yang kurang didukung keluarga dalam memfasilitasi IMD akan berisiko 18,0 kali pada tidak berhasil melaksanakan IMD dibandingkan dengan ibu yang didukung keluarga memfasilitasi IMD.

Kegiatan untuk inisiasi menyusu dini diperlukan dukungan keluarga. Keberhasilan inisiasi menyusu dini didukung oleh peranan keluarga dalam memberikan arahan dan bimbingan yang positif dari tercapai kegiatan inisiasi menyusu dini ibu dan bayinya sesaat sesudah lahir (Roesli, 2012)

Lingkungan keluarga merupakan lingkungan yang sangat berpengaruh terhadap keberhasilan ibu menyusui bayinya secara esklusif. Keluarga (suami, orang tua, mertua, ipar) perlu diinformasikan bahwa seorang ibu perlu dukungandan bantuan keluarga agar ibu 
berhasil menyusui secara eksklusif. Bagian keluarga yang mempunyai pengaruh paling besar terhadap keberhasilan dankegagalan menyusui adalah suami. Masih banyak suami yang berpendapat salah,yang menganggap menyusui adalah urusan ibu dan bayinya. Peranan suami turut menentukan kelancaran refleks pengeluaran ASI (let down reflek) yang sangatdipengaruhi oleh keadaan emosi atau perasaan ibu (Roesli, 2012).

Penelitian yang dilakukan oleh Arifiyanti (2010), menunjukkan bahwa ada hubungan antara dukungan keluarga dengan pemberian kolostrum.

Menurut penelitian Khoniasari (2015) menjelaskan hasil penelitian menunjukkan bahwa variable dukungan keluarga, secara statistic tidak berpengaruh terhadap pelaksanaan IMD. Fakta hasil penelitian ini menunjukkan, bahwa tidak ada perbedaan yang bermakna antara ibu yang memiliki dukungan keluarga lemah dan ibu yang memiliki dukungan tenaga kuat terhadap pelaksanaan IMD Informasi hasil penelitian ini setidaknya sejalan dengan hasil penelitian yang dilakukan oleh Fikayati dan Safiq (2009) yang menunjukkan, bahwa peran suami dan orang tua tidak begitu besar. Meski tampak bahwa peran orangtua (ibu atau mertua) lebih besar dari peran suami. Suami lebih banyak mendukung apapun yang dilakukan oleh ibu. Sedangkan, orangtua biasanya mempengaruhi ibu untuk segera memberi makanan/minuman tambahan kepada bayi. Banyak orangtua yang tidak mengetahui bahwa dengan berkembangnya ilmu pengetahuan pemberian hanya ASI saja sebaiknya 6 bulan dan tidak boleh terlalu dini. Berdasarkan kajian penelitian dan pustaka, maka hasil penelitian dapat disimpulkan bahwa dukungan keluarga merupakan factor yang paling berpengaruh terhadap pelaksanaan IMD pada ibu bersalin

\section{SIMPULAN}

Sebagian besar ibu berhasil melakukan IMD pada 1 jam pertema $(53,6 \%)$. Pengeluaran kolostrum separuh responden mengeluarkan kolostrum (50\%), sebagian besar tenaga kesehatan memfasilitasi pelaksanaan IMD (89,3), sebagian besar keluarga kurang mendukung pelaksanaan IMD $(53,6 \%)$. Ada hubungan pengeluaran kolostrum dengan pelaksanaan inisiasi menyusui dini pada ibu bersalin ( $p$ value $=0,023$ ), tidak ada hubungan peran petugas kesehatan dengan dengan pelaksanaan inisiasi menyusui dini pada ibu bersalin ( $p$ value $=0,583$ ) dan ada hubungan dukungan keluarga dengan dengan pelaksanaan inisiasi menyusui dini pada ibu bersalin ( $\mathrm{p}$ value = 0,007) Di PMB Pringsewu Lampung.
Dukungan keluarga merupakan faktor yang paling berpengaruh terhadap pelaksanaan IMD pada ibu bersalin $(\mathrm{p}$ value $=0,005)$

\section{SARAN}

Disarankan untuk meneliti intervensi yang dapat meningkatkan dukungan keluarga dan pengeluaran kolostrum sebelum persalinan agar dapat meningkatkan keberhasilan pelaksanaan IMD.

\section{DAFTAR PUSTAKA}

Ariani D, Handayani L. Contribution Factors on Early Initiation of Breastfeeding. International Journal of Public Health Science. Vo.04. No. 03. Hal 192- 196

Depkes. (2009). Pelatihan Konseling Menyusui : Sejak Lahir Sampai Enam Bulan Hanya ASI Saja. Jakarta : Depkes RI

Dinkes Pringsewu. (2017). Strategis Kabupaten Pringsewu 2017-2022.

Fikawati, S \& Syafiq, A.(2009). "Penyebab Keberhasilan dan Kegagalan Praktik Pemberian ASI Eksklusif". Jurnal Kesehatan Masyarakat Nasional Vol.4, No.3, Desember 2009.

Fitriana. (2017) Pendampingan Suami pada Ibu Bersalin Berhubungan dengan Keberhasilan Inisiasi Menyusu Dini. Jurnal Ners dan Kebidanan Indonesia. Vol 5 nomor 2, Hal 139-143

Kemenkes. (2013). Riset Kesehatan Dasar. Jakarta. Kementrian Kesehatan RI

Khanal V, Scott JA, Lee AH, Karkee R, Binns CW. Factors associated with Early Initiation of Breastfeeding in Western Nepal. Int. J. Environ. Res. Public Healt. Vo. 2015 No. 12. Hal 113

Khoniasari, A. (2015). Pengaruh Paritas, Pengetahuan Ibu, Dukungan Keluarga, Dan Peran Tenaga Kesehatan Terhadap Pelaksanaan Inisiasi Menyusu Dini Di RSUD Salatiga. Tesis. Universitas Sebelas Maret

Maryunani, Anik. (2012). inisiasi menyusu dini, ASI ekslusif dan manajemen laktasi. Jakarta:TransInfo Media 
Prasetyono D. (2012). Buku Pintar ASI Eksklusif:Pengenalan, Praktik, dan Kemanfaatan.Yogyakarta: Diva Press

Ramadhanti IP. (2016). Analisis FaktorFaktor Yang Mempengaruhi Keberhasilan Inisiasi Menyusui Dini Di Bidan Praktek Swasta Paulina Bukittinggi 2015. Jurnal Kesehatan Roesli. (2012). Inisiasi Menyusu Dini Plus ASI Eksklusif. Jakarta : Pustaka Bunda.
Saleh, La Ode Amal. (2011). Faktor-Faktor Yang Menghambat Praktik ASI Eksklusif Pada bayi Usia 0-6 Bulan (Studi Kualitatif di Desa Tridana Mulya, Kec.Landono Kab.Konawe Selatan, Sulawesi Tenggara).

SDKI. (2012). Indonesia Demographic Health Survey. Jakarta: Kementrian Kesehatan RI

Sulistyawati, A., \& Nugraheny, E, (2012). Asuhan Kebidanan Pada Ibu Bersalin. Jakarta: Salemba Med 
